\title{
Spironolactone inhibits podocyte motility via decreasing integrin $\beta 1$ and increasing integrin $\beta 3$ in podocytes under high-glucose conditions
}

\author{
ZHUO LI ${ }^{1,2}$, LI ZHANG $^{2}$, WEI SHI ${ }^{2}$, YUANHAN CHEN $^{2}$, HONG ZHANG $^{2}$, SHUANGXIN LIU $^{2}$, \\ XINLING LIANG ${ }^{2}$, TING LING ${ }^{2}$, CHUNPING YU $^{2}$, ZHONGSHUN HUANG ${ }^{1,2}$, XIAOFAN TAN $^{1,2}$, \\ XINCHEN ZHAO ${ }^{1,2}$, ZHIMING YE $^{2}$, BIN ZHANG $^{2}$, WENJIAN WANG ${ }^{2},{\text { RUIZHAO } I^{2} \text { and JIANCHAO MA }}^{2}$ \\ ${ }^{1}$ Graduate School, Southern Medical University, Guangzhou, Guangdong 510515; ${ }^{2}$ Department of Nephrology, \\ Guangdong General Hospital, Guangdong Academy of Medical Sciences, Guangzhou, Guangdong 510080, P.R. China
}

Received November 11, 2014; Accepted July 29, 2015

DOI: $10.3892 / \mathrm{mmr} .2015 .4295$

\begin{abstract}
Integrin $\beta 1$ and $\beta 3$ expression by podocytes is required to maintain glomerular structural integrity. Previous studies have shown that aldosterone (ALD) is involved in glomerular podocyte injury, and mineralocorticoid receptor (MR) blocker spironolactone effectively reduces proteinuria in patients with diabetic nephropathy. The present study was designed to observe the effects of spironolactone on $\beta 1$ and $\beta 3$ integrin expression and podocyte motility under in vitro diabetic conditions. Immortalized mouse podocytes were cultured in media containing normal glucose (NG) levels, high glucose $(\mathrm{HG})$ or HG plus spironolacton. The expression of $\beta 1$ and $\beta 3$ integrin in podocytes was detected by reverse transcription quantitative polymerase chain reaction, immunofluorescence and western blot analyses. The effects of spironolacton on podocyte motility was further evaluated using a wound healing assay. HG stimulation markedly decreased mRNA and protein expression of integrin $\beta 1$, and significantly increased mRNA and protein expression of integrin $\beta 3$ in cultured podocytes. However, simultaneous treatment with spironolacton $\left(10^{-7} \mathrm{~mol} / \mathrm{l}\right)$ significantly attenuated $\mathrm{HG}$-mediated increases in integrin $\beta 3$ and decreases in integrin $\beta 1$ expression. Furthermore, the migration of podocytes induced by HG was abrogated by concomitant treatment with spironolacton. In conclusion, the present study suggested that HG decreased the expression of integrin $\beta 1$ in cultured podocytes, accompanied with an increase of integrin $\beta 3$. Spironolactone inhibited cell motility and stabilized podoctyes treated with $\mathrm{HG}$, probably through partly normalizing
\end{abstract}

Correspondence to: Professor Wei Shi, Department of Nephrology, Guangdong General Hospital, Guangdong Academy of Medical Sciences, 106 Zhongshan No. 2 Road, Guangzhou, Guangdong 510080, P.R. China

E-mail: shiweigd139@163.com

Key words: spironolactone, integrin $\beta 1$, integrin $\beta 3$, podocyte the expression of integrin $\beta 1$ and decreasing the expression of integrin $\beta 3$.

\section{Introduction}

Diabetic nephropathy (DN) is a serious and common complication of diabetes type I and II, leading to end-stage renal disease (ESRD) $(1,2)$. Accumulating evidence suggested that glomerular podocytes have a pivotal role in the pathogenesis of diabetic kidney disease $(3,4)$. Podocytes are terminally differentiated cells residing on the outer surface of the glomerular basement membrane (GBM) and have a key role in maintaining the structure and function of the glomerular filtration barrier (3). Previous studies have demonstrated podocyte depletion and loss in the early stages of DN $(5,6)$. These stages of podocyte depletion are accompanied by corresponding degrees of proteinuria $(7,8)$. Therefore, establishment of novel and innovative therapeutic strategies targeted to block the shedding of podocytes, decrease proteinuria and delay the progression of DN has become increasingly urgent.

Integrins are heterodimeric transmembrane adhesion receptors composed of $\alpha$ - and $\beta$-sub-units. Binding of extracellular matrix molecules or other ligands to the extracellular domain of integrins delivers a variety of signals into the cell. Integrins have key roles in a number of important biological processes, including migration, survival, proliferation, gene expression and receptor tyrosine kinase signaling $(9,10)$. Integrin $\alpha 3 \beta 1$ is the principal adhesion complex which is responsible for the attachment of podocytes to the GBM. An in vitro study has demonstrated that high-glucose conditions decreased $\alpha 3 \beta 1$ integrin expression in rat and human podocytes (11). Genetic ablation of $\beta 1$ integrin in mice was shown to cause embryonic lethality shortly after implantation (12). Mice featuring knockout of podocyte-specific Itgbl, which encodes $\beta 1$ integrin, were shown to develop a similar phenotype to podocyte-specific Itga3-knockout mice, with massive proteinuria soon after birth, a laminated GBM with extensive splitting, and foot process effacement followed by mortality within 1-5 weeks due to ESRD (13.14). Besides $\beta 1$ integrins, $\alpha v \beta 3$ integrin is highly expressed in glumerular 
podocytes $(15,16)$. In mice and humans, activation of $\alpha v \beta 3$ by the (soluble) urokinase receptor (UPAR) was demonstrated to result in foot process effacement, proteinuria and focal segmental glomerulosclerosis $(15,17)$. Inhibition of $\alpha v \beta 3$ with an anti- $\beta 3$ antibody or the small-molecule inhibitor cilengitide alleviated proteinuria induced by urokinase receptor $(15,17)$.

It has been suggested that aldosterone has an important role in the pathogenesis of DN (18). Podocytes are one type of target cells for the deleterious effects of aldosterone (19). Spironolactone (SPL), a non-selective aldosterone receptor blocker, was reported to exert beneficial effects not only by reducing proteinuria but delaying DN progression $(20,21)$. Similarly, a previous study demonstrated that SPL prevents podocytic adhesion in streptozotocin-induced diabetic rats, decreases urine albumin and podocyte levels, and upregulates integrin $\alpha 3$ expression (22). However, whether spironolactone has an effect on $\beta 1$ and $\beta 3$ integrin has remained elusive.

Based on the abovementioned findings, the present study was designed to observe whether spironolactone has an impact on integrin $\beta 1$ and $\beta 3$ expression, and podocyte motility under in vitro diabetic conditions.

\section{Materials and methods}

Drugs and reagents. Spironolactone (S3378), D-glucose (G7021) and mannitol (M9647) were purchased from Sigma-Aldrich (St. Louis, MO, USA). Dulbecco's modified Eagle's medium (DMEM) was obtained from Corning, Inc. (Corning, NY, USA). Fetal bovine serum (FBS), recombinant interferon $\gamma$ and rat tail collagen type I were purchased from Invitrogen Life Technologies, Inc., (Carlsbad, CA, USA), ProSpec Tany Technogene Ltd. (East Brunswick, NJ, USA) and BD Biosciences (Franklin Lakes, NJ, USA), respectively. All primary antibodies, including rabbit polyclonal antibody integrin $\beta 1$ (cat. no. sc-8978), rabbit polyclonal anti-integrin $\beta 3$ (cat. no. sc-14009), goat polyclonal anti-synaptopodin (N-14; cat. no. sc-21536) and mouse monoclonal anti-GAPDH (cat. no. sc-365062), were purchased from Santa Cruz Biotechnology, Inc. (Dallas, TX, USA). Fluorescein isothiocyanate-conjugated (FITC)-donkey anti-goat immunoglobulin (Ig)G (H+L; cat. no. sc-2024) and goat anti-rabbit Alexa Fluor 555 (cat. no. sc-362272) were obtained from Santa Cruz Biotechnology, Inc., and Cell Signaling Technology, Inc. (Beverly, MA, USA), respectively. Dimethyl sulfoxide (DMSO) and TRIzol were purchased from Sigma-Aldrich (St. Louis, MO, USA) and Invitrogen Life Technologies, Inc, respectively. PrimeScript 1st Strand cDNA Synthesis kit (cat. no. RR001A) and SYBR Premix Ex Taq Green kit (cat. no. RR420A) were purchased from Takara Biotechnology Inc. (Dalian, China). A radioimmunoprecipitation assay (RIPA) protein extraction kit (cat. no. C1053) and bicinchoninic acid (BCA) Protein Assay kit (cat. no. FD2001) were purchased from Puli Lai company (Beijing, China) and Fabio Science company (Hangzhou, China), respectively.

Cell culture and treatment. The conditionally immortalized mouse podocyte cell line (MPC) was kindly provided by Dr. Jochen Reiser (Rush University Medical Center, Chicago, IL, USA) and were cultured as previously described (23). Differentiated podocytes (passage 13-18) were serum-starved for $24 \mathrm{~h}$ and then treated with normal glucose (NG; $5.3 \mathrm{mM}$ ), high glucose $(\mathrm{HG} ; 20 \mathrm{mM})$ or with $\mathrm{NG}(5.3 \mathrm{mM})$ plus mannitol (14.7 mM; osmolality control) for $48 \mathrm{~h}$ prior to the assays. For intervention experiments, aldosterone receptor blocker SPL (Sigma-Aldrich) at concentrations of $10^{-8} \mathrm{~mol} / \mathrm{l}$ and $10^{-7} \mathrm{~mol} / \mathrm{l}$ was respectively added to cells treated with $\mathrm{HG}$ at a concentration of $20 \mathrm{mM}$ for $48 \mathrm{~h}$.

Reverse transcription quantitative polymerase chain reaction $(R T-q P C R)$. TRIzol reagent was used to extract the total RNA from the cultured podocytes from the experimental groups according to the manufacturer's instructions (Invitrogen Life Technologies, Inc.). The complementary DNA was synthesized using 1,000 ng RNA in $20 \mu \mathrm{l}$ using the PrimerScript ${ }^{\mathrm{TM}}$ RT Regent kit (cat. no. RR001A; Takara Biotechnology Inc.) according to the manufacturer's instructions. RT-PCR was performed with a Bio-Rad CFX96 Touch q-PCR system (Bio-Rad Laboratories, Inc., Hercules, CA, USA) using Power SYBR Green PCR Master Mix with the cDNA and primer pairs (Invitrogen Life Technologies). The sequences of primer pairs used for real-time PCR were as follows: Integrin $\beta 1$ forward, 5'-GGCTGAAGATTACCCTAT-3' and reverse, 5'-CATTCA TCAAATCCGTTC-3'; integrin $\beta 3$ forward, 5'-GCCTTCGTG GACAAGCCTGTA-3' and reverse, 5'-GGACAATGCCTG CCAGTCTTC-3'; GAPDH forward, 5'-TGTGTCCGTCGT GGATCTGA-3' and reverse, 5'-TTGCTGTTGAAGTCGCAG GAG-3'. The PCR conditions were as follows: An initial step of $2 \mathrm{~min}$ at $95^{\circ} \mathrm{C}$, followed by 40 cycles of $5 \mathrm{sec}$ at $95^{\circ} \mathrm{C}, 25 \mathrm{sec}$ at $60^{\circ} \mathrm{C}$, and $40 \mathrm{sec}$ at $72^{\circ} \mathrm{C}$. Every reaction was amplified in triplicate and the fold change in the expression of each gene was calculated using $\Delta \Delta \mathrm{Ct}$ method with GAPDH mRNA as an internal control.

Immunofluorescence staining. After being subjected to various treatments, podocytes were fixed with $4 \%$ paraformaldehyde at $-20^{\circ} \mathrm{C}$ for $20 \mathrm{~min}$ and then incubated with $5 \%$ BSA for $20 \mathrm{~min}$ at RT to block non-specific binding. Samples were incubated with the primary antibodies overnight at $4^{\circ} \mathrm{C}$, followed by $1 \mathrm{~h}$ of incubation with secondary antibodies goat anti-rabbit Alexa Fluor 555 (1:1,000) or FITC-donkey anti-goat IgG $(\mathrm{H}+\mathrm{L})(1: 250)$ at room temperature, followed by counterstaining with DAPI (Roche Diagnostics, Basel, Switzerland) for $5 \mathrm{~min}$ to visualize the nuclei. After being washed, the slides were mounted with anti-fade mounting medium (Beyotime Institute of Biotechnology, Haimen, China). Photomicrographs were captured using confocal microscopy (Leica SP5-FCS; Leica Microsystems, Oberkochen, Germany). The primary antibodies used in the present study were as follows: Rabbit polyclonal anti-integrin $\beta 1$ (1:100), rabbit polyclonal anti-integrin $\beta 3$ (1:100) and goat polyclonal anti-synaptopodin (N-14) (1:100). All images were analyzed by two investigators blinded to the identity of the samples.

Western blot analysis. Differentiated podocytes, subjected to various experimental conditions, were washed twice with cold phosphate-buffered saline (PBS). The washed podocytes were drained and scraped with RIPA lysis buffer using a cold plastic cell scraper. Protein concentration was quantified using the BCA Protein Assay Reagent kit. An aliquot of cell lysates containing $30 \mu \mathrm{g}$ protein was separated by $8 \%$ SDS-PAGE 
A

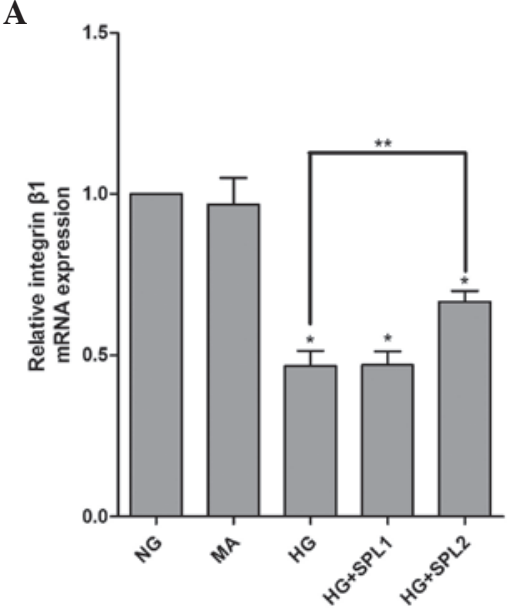

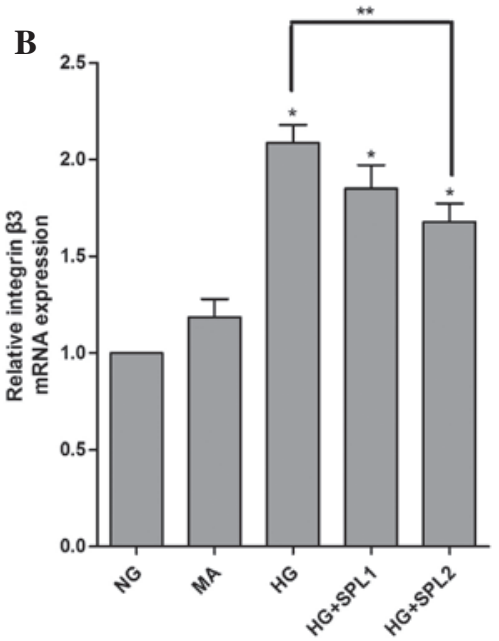

Figure 1. mRNA levels of integrin $\beta 1$ and $\beta 3$ in cultured podocytes under various experimental conditions. (A) mRNA levels of integrin $\beta 1$ and (B) integrin $\beta 3$ were examined using reverse transcription quantitative polymerase chain reaction analysis. GAPDH mRNA was used as an internal control. Quantitative values were obtained using the $2^{-\triangle \Delta C T}$ method. Values are expressed as the mean \pm standard deviation of assays performed in triplicate. ${ }^{*} \mathrm{P}<0.05$ vs. NG group. ${ }^{* *} \mathrm{P}<0.05, \mathrm{HG}+\mathrm{SPL} 2$ vs. HG. Groups: NG, normal glucose $(5.3 \mathrm{Mm}) ; \mathrm{HG}$, high glucose $(20 \mathrm{mM})$; MA, normal glucose $(5.3 \mathrm{mM})+\mathrm{mannitol}(14.7 \mathrm{mM})$, as an osmolality control; HG + SPL1, high glucose $(20 \mathrm{mM})+$ spironolactone $\left(10^{-8} \mathrm{~mol} / \mathrm{l}\right) ; \mathrm{HG}+\mathrm{SPL} 2$, high glucose $(20 \mathrm{mM})+\mathrm{spironolactone}\left(10^{-7} \mathrm{~mol} / 1\right)$.

and transferred onto a polyvinylidene fluoride membrane (Millipore, Billerica, MA, USA). Membranes were blocked with $5 \%$ fat-free milk for $1 \mathrm{~h}$ at room temperature and then incubated overnight at $4^{\circ} \mathrm{C}$ with the following primary antibodies: Rabbit polyclonal anti-integrin $\beta 1(1: 1,000)$, rabbit polyclonal anti-integrin $\beta 3(1: 1,000)$ and mouse monoclonal anti-GAPDH (1:2,000). After washing, HRP-conjugated goat anti-rabbit IgG or goat anti-mouse IgG (Jackson Immuno Research, West Grove, PA, USA, 1:5,000) was added and incubated $1 \mathrm{~h}$ at room temperature. The immunoblots were washed three times with Tris-buffered staline containing Tween 20 and immersed in ECL Plus Western Blotting Detection Reagents (Beyotime Institute of Biotechnology). Results were analyzed using Image J v1.47 software (National Institutes of Health, Bethesda, MD, USA) and normalized to the protein expression of GAPDH.

Wound healing assay. Cultured differentiated podocytes $\left(1 \times 10^{5} / \mathrm{ml}\right)$ were seeded overnight on vitronectin-coated coverslips in six-well plates. Each coverslip was then scratched with a sterile $200-\mu$ l pipette tip, washed with PBS and placed into fresh medium. After $24 \mathrm{~h}$, cells were fixed with cold methanol, permeabilized with $0.5 \%$ Triton $\mathrm{X}-100$ in PBS and cell nuclei were stained with DAPI (Roche Diagnostics). Images were captured by phase-contrast microscopy under a x10 objective on a Leica SP5-FCS microscope (Leica Microsystems) at 0 and $24 \mathrm{~h}$ after scratching, and the numbers of cells that had migrated into the same-sized square fields were counted. Results are presented presented as the mean \pm standard deviation (SD) of six independent experiments.

Statistical analysis. Values are expressed as the mean \pm SD. Statistical analysis was performed by SPSS 17.0 (SPSS Inc, Chicago, IL,USA) using analysis of variance followed by Bonferoni's multiple comparisons test. $\mathrm{P}<0.05$ was considered to indicate a significant difference between values.

\section{Results}

$H G$ decreases integrin $\beta 1$ and increases integrin $\beta 3$ expression in cultured podocytes. To determine the effects of $\mathrm{HG}$ on integrin $\beta 1$ and integrin $\beta 3$, podocytes were cultured in DMEM containing $5.3 \mathrm{mM}$ glucose (NG group), $5.3 \mathrm{mM}$ glucose plus $14.7 \mathrm{mM}$ mannitol (M group, as an osmolality control) or $20 \mathrm{mM}$ glucose (HG group) for $48 \mathrm{~h}$. The mRNA and protein expression of integrin $\beta 1$ and integrin $\beta 3$ were determined using RT-qPCR and western blot analysis. As shown in Fig. 1A, the mRNA expression of integrin $\beta 1$ was significantly decreased in the HG group compared to that in the NG group $(\mathrm{P}<0.001)$. By contrast, the mRNA levels of integrin $\beta 3$ were markedly increased in podocytes incubated with $\mathrm{HG}$ for $48 \mathrm{~h}$ (Fig. 1B). Immunofluorescent staining and western blot analysis also showed a decreased protein expression of integrin $\beta 1$ and an increased protein expression of integrin $\beta 3$ in the HG group (Figs. 2 and 3). As expected, mannitol had no effect on the mRNA expression of integrin $\beta 1$ and integrin $\beta 3$, suggesting that the decreased integrin $\beta 1$ and $\beta 3$ mRNA expression under HG did not result from high osmolality.

SPL normalizes integrin $\beta 1$ and integrin $\beta 3$ expression in podocytes under $H G$. To evaluate the effects of SPL on the expression of integrin $\beta 1$ and integrin $\beta 3$ in $\mathrm{HG}$-cultured podocytes, cells incubated under various conditions were analyzed using RT-qPCR, immunoblotting and immunofluorescence. As shown in Fig. 1A, the HG-mediated decrease in integrin $\beta 1 \mathrm{mRNA}$ expression in podocytes was significantly attenuated by SPL $\left(10^{-7} \mathrm{~mol} / \mathrm{l}\right)(\mathrm{P}<0.01)$. Similarly, immunofluorescence and western blot analysis demonstrated that decreases in integrin $\beta 1$ protein expression in HG-cultured podocytes were restored by SPL $\left(10^{-7} \mathrm{~mol} / \mathrm{l}\right)$ (Fig. 2A, and $3 \mathrm{~A}$ and $\mathrm{B})$. Furthermore, the significant $\mathrm{HG}$-induced increase in the expression of integrin $\beta 3$ was reduced by treatment with SPL $\left(10^{-7} \mathrm{~mol} / \mathrm{l}\right)$ at the mRNA level (Fig. 1B) and at the protein level (Figs. 2B, and 3A and C). However, a low dose of SPL 


\section{DAPI synaptopodin Integrin $\beta 1$ overlap}

NG

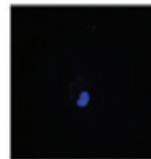

HG
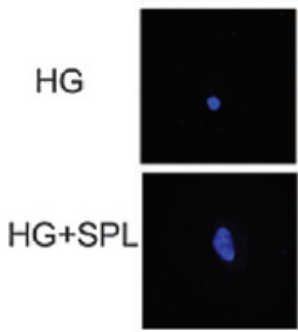
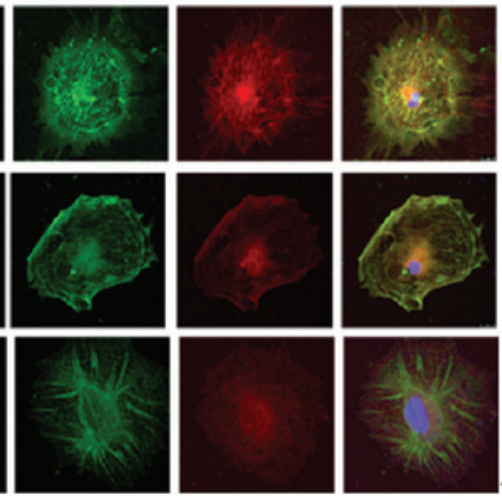

B

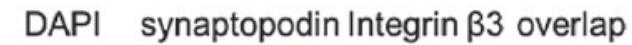

NG
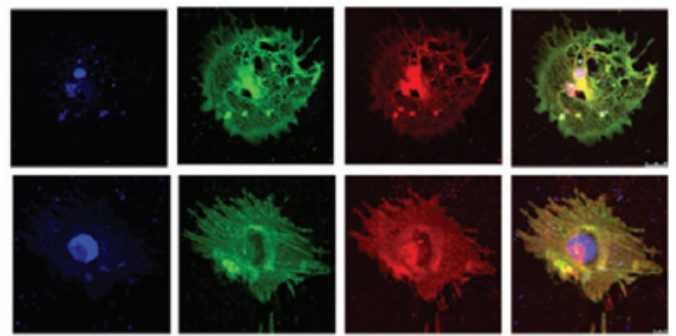

HG
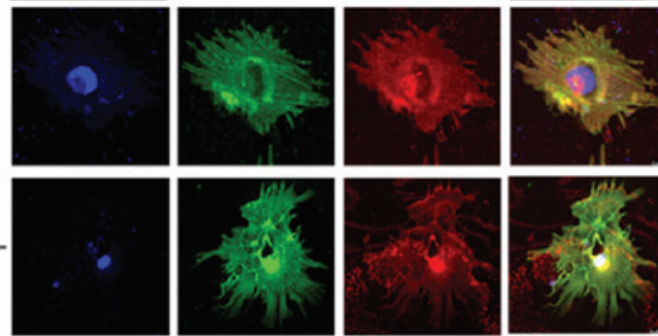

Figure 2. Effects of spironolactone on integrin $\beta 1$ and $\beta 3$ expression were analyzed by immunofluorescent staining in podocytes under HG conditions (A) Double immunofluorescent staining of integrin $\beta 1$ (red), synaptopodin (green), DAPI-stained nuclei (blue) and merged images in cultured podocytes treated with NG, HG and HG plus SPL for 48 h, respectively. (B) Double immunofluorescent staining of integrin $\beta 3$ (red), synaptopodin (green), DAPI-stained nuclei (blue) and merged images in cultured podocytes treated with NG, HG and HG plus SPL for 48 h, respectively. NG, normal glucose (5.3 Mm); HG, high glucose $(20 \mathrm{mM}) ; \mathrm{HG}+\mathrm{SPL}$, high glucose $(20 \mathrm{mM})+$ spironolactone $\left(10^{-7} \mathrm{~mol} / \mathrm{l}\right)$.

$\mathbf{B}$

A

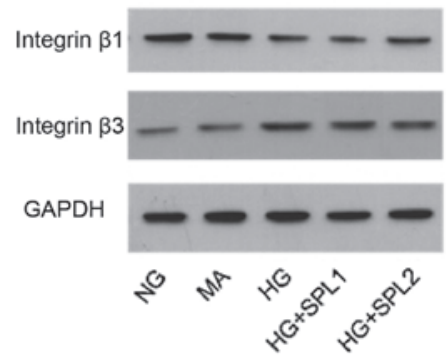

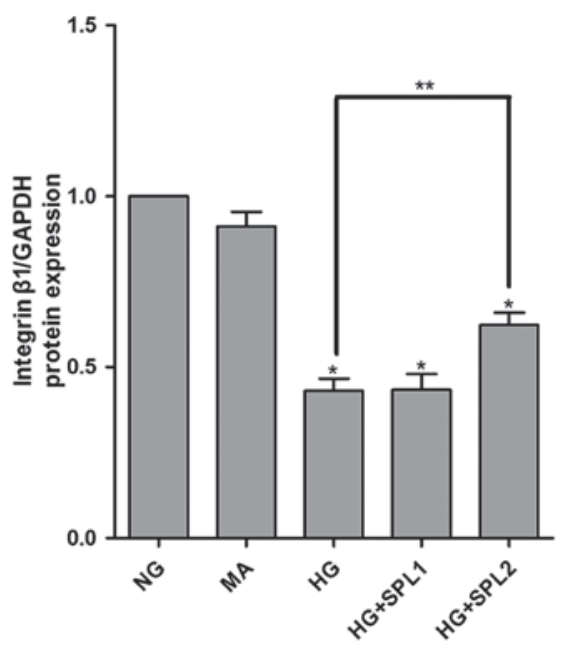

C

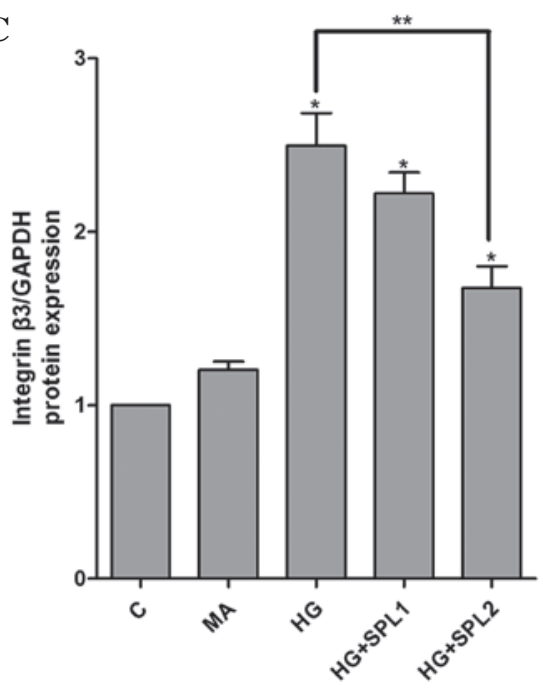

Figure 3. Effects of spironolactone on integrin $\beta 1$ and $\beta 3$ expression in podocytes under HG conditions were analyzed by immunoblotting. (A) Protein levels of integrin $\beta 1$ and $\beta 3$ expression in podocytes under various conditions were analyzed using immunoblotting. Densitometric analysis of three repetitions of (B) integrin $\beta 1$ and $(C)$ integrin $\beta 3$ protein. All Values are expressed as the mean \pm standard deviation. ${ }^{*} \mathrm{P}<0.05$ vs. NG; ${ }^{* *} \mathrm{P}<0.05$ vs. HG. Groups: $\mathrm{C}$, control; NG, normal glucose $(5.3 \mathrm{Mm})$; HG, high glucose $(20 \mathrm{mM})$; MA, normal glucose $(5.3 \mathrm{mM})+$ mannitol $(14.7 \mathrm{mM})$, as an osmolality control; HG + SPL1, high glucose $(20 \mathrm{mM})+$ spironolactone $\left(10^{-8} \mathrm{~mol} / \mathrm{l}\right) ; \mathrm{HG}+\mathrm{SPL} 2$, high glucose $(20 \mathrm{mM})+$ spironolactone $\left(10^{-7} \mathrm{~mol} / \mathrm{l}\right)$.

A

NG

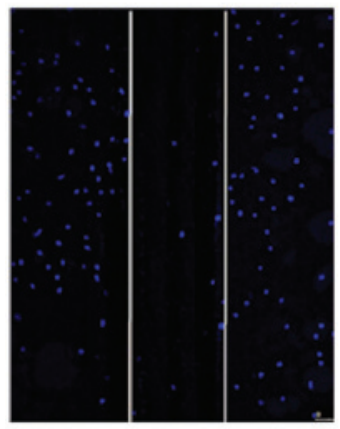

B

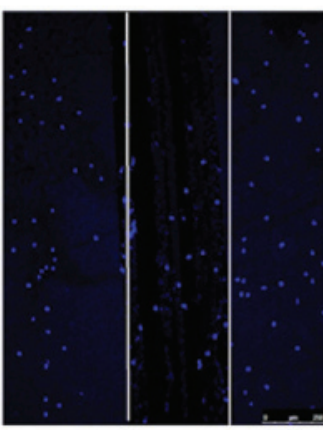

C

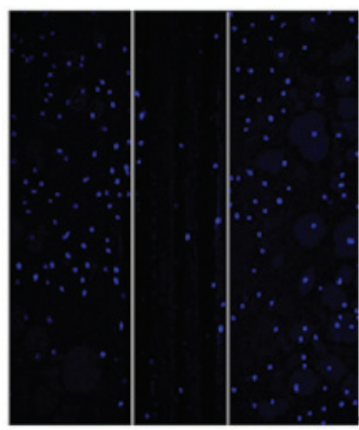

D

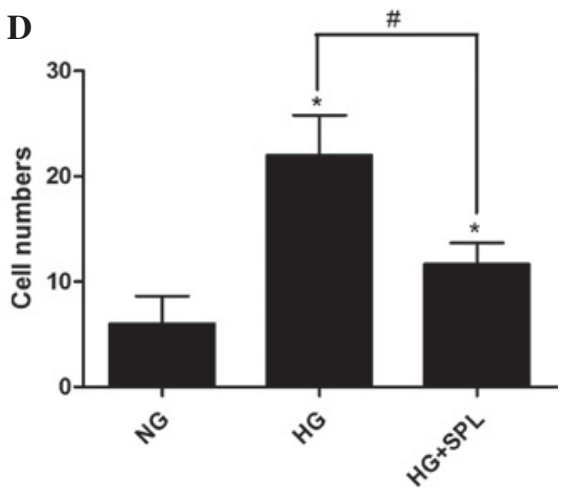

Figure 4. Spironolactone inhibits podocyte motility induced by HG. (A) NG group. (B) HG treatment significantly promoted podocyte wound closure (22.0 44.0 vs. 6.0 $\pm 3.0 ; \mathrm{P}<0.001$ ). (C) By contrast, treatment with spironolactone reduced HG-induced podocyte motility $(12.0 \pm 2.0$ vs. 22.0 $\pm 4.0 ; \mathrm{P}<0.05)$. (D) Quantified numbers of migrated podocytes. All Values are expressed as the mean \pm standard deviation. Magnification, $\mathrm{x} 100 .{ }^{*} \mathrm{P}<0.05 \mathrm{vs}$. NG; ${ }^{\text {"P }}<0.05$ vs. HG. NG, normal glucose $(5.3 \mathrm{Mm})$ group; HG, high glucose $(20 \mathrm{mM}) ; \mathrm{HG}+\mathrm{SPL}$, high glucose $(20 \mathrm{mM})+$ spironolactone $\left(10^{-7} \mathrm{~mol} / \mathrm{l}\right)$. 
$\left(10^{-8} \mathrm{~mol} / \mathrm{l}\right)$ did not affect integrin $\beta 1$ and integrin $\beta 3$ expression in podocytes cultured under HG $(\mathrm{P}>0.05)$ (Figs. 1 and 3 ).

SPL inhibits podocyte motility induced by HG. Podocyte motility is regarded as a surrogate indicator for proteinuria and effacement of podocyte foot processes in vivo $(15,17,24)$. Therefore, the present study next explored whether SPL has a role in inhibiting cell motility of podocytes in vitro. The effects of SPL on the spatial motility of podocytes was analyzed using a scrape-wound assay (Fig. 4). As compared with the control $(6.0 \pm 3.0)$, HG treatment significantly promoted podocyte wound closure $(22.0 \pm 4.0 ; \mathrm{P}<0.05)$ (Fig. $4 \mathrm{~A}, \mathrm{~B}$ and D). By contrast, treatment with SPL reduced $\mathrm{HG}$-induced podocyte motility $(12.0 \pm 2.0 ; \mathrm{P}<0.05)$ (Fig. $4 \mathrm{C}$ and $\mathrm{D})$. These results demonstrated that SPL inhibits podocyte motility induced by HG.

\section{Discussion}

The incidence of diabetes has been increasing on a yearly basis; in addition, DN has gradually become a severe complication in patients with diabetes $(1,2)$. Experimental and clinical studies have shown that a decrease in the number of podocytes due to shedding or apoptosis leads to proteinuria in DN $(5,6,25)$. Apart from the administration of angiotensin-converting enzyme inhibitors, angiotensin receptor blockers and other drugs, no other treatments for effectively lowering urinary protein and delaying disease progression are currently available. As a novel approach for the development of therapies for the treatment of $\mathrm{DN}$, the prevention or inhibition of podocyte shedding or apoptosis is an obvious and promising therapeutic target.

Under normal circumstances, podocytes are anchored to the GBM through the $\alpha 3 \beta 1$-integrin complex that is present in the sole of the foot processes. However, under pathological conditions, resembled by a rat model of diabetes or podocytes cultured under $\mathrm{HG}$, podocyte shedding or podocye motility were increased, accompanied by changes in the levels of integrin, which was observed at early stages of DN $(5,6,26)$. Therefore, blocking this process by increasing the levels of integrin $\beta 1$ is expected to enable podocytes to closely attach to the GBM. In addition, a recent study by our group showed that uPAR expression was increased in HG-cultured podocytes and DN patients (27). Previous studies have demonstrated that UPAR and integrin $\beta 3$ co-localize in podocytes and form a lipid-dependent complex with integrin $\beta 3$, thereby causing a structural configurational change of integrin $\beta 3$, resulting in its activation with increased affinity for ligand binding $(5,6)$. In vivo gene delivery of a structurally fixed and constitutively active integrin $\beta 3$ was shown to be sufficient to induce proteinuria in mice; conversely, the inhibition of uPAR expression and integrin $\beta 3$ activation improved the structure of the podocyte foot process and had an anti-proteinuric effect (24). Therefore, the present study addressed the question whether decreased expression of integrin $\beta 3$ by drug intervention under diabetic conditions can inhibit podocyte motility.

The results of the present study demonstrated that $\mathrm{HG}$ decreased integrin $\beta 1$ expression and increased integrin $\beta 3$ expression, accompanied by increased podocyte motility. In HG-cultured podocytes treated with various concentrations of
SPL, a non-selective aldosterone receptor antagonist, changes in integrin $\beta 1$ and integrin $\beta 3$ expressions were partially normalized by high concentrations of SPL $\left(10^{-7} \mathrm{~mol} / \mathrm{l}\right)$. HG-induced decreases in integrin $\beta 1$ expression increases in integrin $\beta 3$ expression and increases in podocyte motility were significantly attenuated by SPL. However, a low concentration of SPL $\left(10^{-8} \mathrm{~mol} / \mathrm{l}\right)$ had no marked effects on HG-induced changes in integrin expression and podocyte motility. Whether the attenuating effects of SPL on the HG-induced effects on podocytes are based on respective interactions with the two integrin $\beta$ sub-units or on mutual reactions between integrin $\beta 1$ and integrin $\beta 3$ themselves remains elusive. A cancer-associated study reported that integrin $\alpha 3 \beta 1$ inhibits integrin $\alpha v \beta 3$ expression (28). Hence, it was hypothesized in the present study that, under physiological conditions, integrin $\beta 1$ expression in podocytes may inhibit the expression of integrin $\beta 3$. However, under pathological conditions, the role of inhibited integrin $\beta 3$ is expected to be attenuated due to decreased levels of integrin $\beta 1$. In the present study, decreases in integrin $\beta 1$ and increases in integrin $\beta 3$ expression were attenuated by co-incubation with SPL in HG-cultured podocytes.

Recent clinical and experimental studies have demonstrated that aldosterone has pathogenetic roles in podocyte injury and DN $(18,19,29)$. Aldosterone is a potent inducer of proteinuria. Siragy and Xue (30) demonstrated that diabetes increased local aldosterone production in the kidney, which contributed to the development of renal inflammation, matrix formation and albuminuria. Another previous study also showed that the local aldosterone system is activated and is involved in podocyte apoptosis under diabetic conditions (31). These results suggested that blockade of the aldosterone system may represent a novel therapeutic strategy to prevent proteinuria and podocyte injury under hyperglycemic conditions. In fact, experimental as well as clinical studies have demonstrated renoprotective effects of SPL in DN (20,21,32-37). However, the mechanisms by which SPL attenuates proteinuria and podocyte injury in DN remain to be fully elucidated. The results of the present study revealed that under HG conditions, the expression of integrin $\beta 1$ was increased and integrin $\beta 3$ expression was decreased by SPL, accompanied with the inhibition of podocyte motility. This effect may be one of the possible mechanisms of the protective effects of SPL on podocyte injury.

In conclusion, the present study showed that HG conditions decreased integrin $\beta 1$ and increased integrin $\beta 3$ expression in podocytes, accompanied with enhanced podocyte motility. Treatment with SPL markedly inhibited podocyte motility and partly restored integrin $\beta 1$ and integrin $\beta 3$ expression in this cell model. These results indicated that the effects of SPL on podocyte motility may, proceed via restoring integrin $\beta 1$ and $\beta 3$ expression, which may be one of the underlying mechanisms of its protective effects against podocyte injury under HG conditions.

\section{Acknowledgements}

This study was supported by the National Natural Science Foundation (nos. 81170683, 81270784, S2013040015908 and 81470930) and National Clinical Key Specialty Construction Projects. 


\section{References}

1. Molitch ME, DeFronzo RA, Franz MJ, Keane WF, Mogensen CE, Parving HH and Steffes MW; American Diabetes Association. Nephropathy in diabetes. Diabetes Care 27 (Suppl 1): S79-S83, 2004.

2. Ritz E, Rychlik I, Locatelli F and Halimi S: End-stage renal failure in type 2 diabetes: A medical catastrophe of worldwide dimensions. Am J Kidney Dis 34: 795-808, 1999.

3. Wolf G, Chen S and Ziyadeh FN: From the periphery of the glomerular capillary wall toward the center of disease: Podocyte injury comes of age in diabetic nephropathy. Diabetes 54: 1626-1634, 2005.

4. Li JJ, Kwak SJ, Jung DS, Kim JJ, Yoo TH, Ryu DR, Han SH, Choi HY, Lee JE, Moon SJ, et al: Podocyte biology in diabetic nephropathy. Kidney Int Suppl S36-S42, 2007.

5. Pagtalunan ME, Miller PL, Jumping-Eagle S, Nelson RG, Myers BD, Rennke HG, Coplon NS, Sun L and Meyer TW: Podocyte loss and progressive glomerular injury in type II diabetes. J Clin Invest 99: 342-348, 1997.

6. White KE, Bilous RW, Marshall SM, El Nahas M, Remuzzi G, Piras G, De Cosmo S and Viberti G: Podocyte number in normotensive type 1 diabetic patients with albuminuria. Diabetes 51: 3083-3089, 2002.

7. D'Agati VD: Podocyte injury in focal segmental glomerulosclerosis: Lessons from animal models (a play in five acts) Kidney Int 73: 399-406, 2008

8. Wharram BL, Goyal M, Wiggins JE, Sanden SK, Hussain S, Filipiak WE, Saunders TL, Dysko RC, Kohno K, Hozman LB and Wiggins RC: Podocyte depletion causes glomerulosclerosis: Diphtheria toxin-induced podocyte depletion in rats expressing human diphtheria toxin receptor transgene. J Am Soc Nephrol 16: 2941-2952, 2005.

9. Wu X, Wang J, Jiang H, Hu Q, Chen J, Zhang J, Zhu R, Liu W and $\mathrm{Li} \mathrm{B}$ : Wnt $3 \mathrm{a}$ activates $\beta 1$-integrin and regulates migration and adhesion of vascular smooth muscle cells. Mol Med Rep 9: $1159-1164,2014$

10. Zaidel-Bar R, Itzkovitz S, Ma'ayan A, Iyengar R and Geiger B: Functional atlas of the integrin adhesome. Nat Cell Biol 9: 858-867, 2007

11. Kitsiou PV, Tzinia AK, Stetler-Stevenson WG, Michael AF, Fan WW, Zhou B and Tsilibary EC: Glucose-induced changes in integrins and matrix-related functions in cultured human glomerular epithelial cells. Am J Physiol Renal Physiol 284: F671-F679, 2003.

12. Fassler R and Meyer M: Consequences of lack of beta 1 integrin gene expression in mice. Genes Dev 9: 1896-1908, 1995.

13. Kanasaki K, Kanda Y,Palmsten K, Tanjore H, Lee SB, Lebleu VS and Gattone VH Jr and Kalluri R: Integrin beta1-mediated matrix assembly and signaling are critical for the normal development and function of the kidney glomerulus. Dev Biol 313: 584-593, 2008.

14. Pozzi A, Jarad G, Moeckel GW, Coffa S, Zhang X, Gewin L, Eremina V, Hudson BG, Borza B, Harris RC, et al: Beta1 integrin expression by podocytes is required to maintain glomerular structural integrity. De Biol 316: 288-301, 2008.

15. Wei C, Möller CC, Altintas MM, Li J, Schwarz K, Zacchigna S, Xie L, Henger A, Schmid H, Rastaldi MP, et al: Modification of kidney barrier function by the urokinase receptor. Nat Med 14: 55-63, 2008.

16. Sachs N and Sonnenberg A: Cell-matrix adhesion of podocytes in physiology and disease. Nat Rev Nephrol 9: 200-210, 2013.

17. Wei C, El Hindi S, Li J, Fornoni A, Goes N, Sageshima J, Maiguel D, Karumanchi SA, Yap HK, Saleem M, et al: Circulating urokinase receptor as a cause of focal segmental glomerulosclerosis. Nat Med 17: 952-960, 2011.

18. Cha DR, Kang YS, Han SY, Jee YH, Han KH, Kim HK, Han JY and Kim YS: Role of aldosterone in diabetic nephropathy. Nephrology (Carlton) 10 (Suppl): S37-S39, 2005.

19. Shibata S, Nagase M, Yoshida S, Kawachi H and Fujita $T$ : Podocyte as the target for aldosterone: Roles of oxidative stress and Sgk1. Hypertension 49: 355-364, 2007.
20. Schjoedt KJ, Rossing K, Juhl TR, Boomsma F, Tarnow L, Rossing $\mathrm{P}$ and Parving HH: Beneficial impact of spironolactone on nephrotic range albuminuria in diabetic nephropathy. Kidney Int 70: 536-542, 2006.

21. Aguilar C and Rodríguez-Delfín L: Effects of spironolactone administration on the podocytes loss and progression of experimental diabetic nephropathy. Rev Peru Med Exp Salud Publica 29: 490-497, 2012 (In Spanish).

22. Lin S, Li D, Jia J, Zheng Z, Jia Z and Shang W: Spironolactone ameliorates podocytic adhesive capacity via restoring integrin alpha 3 expression in streptozotocin-induced diabetic rats. J Renin Angiotensin Aldosterone Syst 11: 149-157, 2010.

23. Mundel P, Reiser J, Zúñiga Mejía Borja A, Pavenstadt H, Davidson GR, Kriz W and Zeller R: Rearrangements of the cytoskeleton and cell contacts induce process formation during differentiation of conditionally immortalized mouse podocyte cell lines. Exp Cell Res 236: 248-258, 1997.

24. Zhang B, Xie S, Shi W and Yang Y: Amiloride off-target effect inhibits podocyte urokinase receptor expression and reduces proteinuria. Nephrol Dial Transplant 27: 1746-1755, 2012

25. Weil EJ, Lemley KV, Yee B, Lovato T, Richardson M, Myers BD and Nelson RG: Podocyte detachment in type 2 diabetic nephropathy. Am J Nephrol 33 (Suppl 1): 21-24, 2011.

26. Kitsiou PV, Tzinia AK, Stetler-Stevenson WG, Michael AF, Fan WW, Zhou B and Tsilibary EC: Glucose-induced changes in integrins and matrix-related functions in cultured human glomerular epithelial cells. Am J Physiol Renal Physiol 284: F671-F679, 2003.

27. Zhang L, Li R, Shi W, Liang X, Liu S, Ye Z, Yu C, Chen Y, Zhang B, Wang W, et al: NFAT2 inhibitor ameliorates diabetic nephropathy and podocyte injury in $\mathrm{db} / \mathrm{db}$ mice. Br J Pharmacol 170: 426-439, 2013.

28. Borza CM, Pozzi A, Borza DB, Pedchenko V, Hellmark T, Hudson BG and Zent R. Integrin alpha3beta1, a novel receptor for alpha3(IV) noncollagenous domain and a trans-dominant inhibitor forintegrin alphavbeta3. J Biol Chem 281: 20932-20939, 2006.

29. Nagase M and Fujita T: Aldosterone and glomerular podocyte injury. Clin Exp Nephrol 12: 233-242, 2008.

30. Siragy HM and Xue C: Local renal aldosterone production induces inflammation and matrix formation in kidneys of diabetic rats. Exp Physiol 93: 817-824, 2008.

31. Lee SH, Yoo TH, Nam BY, Kim DK, Li JJ, Jung DS, Kwak SJ, Ryu DR, Han SH, Lee JE, et al: Activation of local aldosterone system within podocytes is involved in apoptosis under diabetic conditions. Am J Physiol Renal Physiol 297: F1381-F1390, 2009.

32. Han SY, Kim CH, Kim HS, Jee YH, Song HK, Lee MH, Han KH, Kim HK, Kang YS, Han JY, et al: Spironolactone prevents diabetic nephropathy through an anti-inflammatory mechanism in type 2 diabetic rats. J Am Soc Nephrol 17: 1362-1372, 2006.

33. Toyonaga J, Tsuruya K, Ikeda H, Noguchi H, Yotsueda H, Fujisaki K, Hirakawa M, Taniguchi M, Masutani K and Iida M: Spironolactone inhibits hyperglycemia-induced podocyte injury by attenuating ROS production. Nephrol Dial Transplant 26: 2475-2484, 2011

34. Taira M, Toba H, Murakami M, Iga I, Serizawa R, Murata S, Kobara M and Nakata T: Spironolactone exhibits direct renoprotective effects and inhibits renal renin-angiotensin-aldosterone system in diabetic rats. Eur J Pharmacol 589: 264-271, 2008.

35. Han KH, Kang YS, Han SY, Jee YH, Lee MH, Han JY, Kim HK, Kim YS and Cha DR: Spironolactone ameliorates renal injury and connective tissue growth factor expression in type II diabetic rats. Kidney Int 70: 111-120, 2006.

36. Nielsen SE, Persson F, Frandsen E, Sugaya T, Hess G, Zdunek D, Shjoedt KJ,Parving HH and Rossing P: Spironolactone diminishes urinary albumin excretion in patients with type 1 diabetes and microalbuminuria: A randomized placebo-controlled crossover study. Diabet Med 29: e184-e190, 2012.

37. Rossing K, Schjoedt KJ, Smidt UM, Boomsma F and Parving HH: Beneficial effects of adding spironolactone to recommended antihypertensive treatment in diabetic nephropathy: A randomized, double-masked, cross-over study. Diabetes Care 28: 2106-2112, 2005. 